\title{
Comparative plant growth promoting traits and distribution of rhizobacteria associated with heavy metals in contaminated soils
}

\author{
${ }^{1}$ M. R. Melo; ${ }^{1}$ N. R. Flores; ${ }^{2}$ S. V. Murrieta; ${ }^{2}$ A. R. Tovar; ${ }^{3}$ A. G. Zúñiga; ${ }^{4}$ O. F. Hernández; ${ }^{5}$ A. P. \\ Mendoza, ${ }^{2,6}$ N. O. Pérez; ${ }^{1} * A$. R. Dorantes \\ ${ }^{I}$ Department of Botany, School of National Biological Sciences, National Polytechnic Institute, 11340, D.F., México \\ ${ }^{2}$ Department of Microbiology, School of National Biological Sciences, National Polytechnic Institute, 11340, \\ D. F., México \\ ${ }^{3}$ Petroleum Mexican Institute 07730, D. F., México \\ ${ }^{4}$ Department of Basic Sciences, Interdisciplinary Professional Unit of Biotechnology, National Polytechnic Institute, \\ 11340, D. F., México \\ ${ }^{5}$ Metropolitan Autonomous University, Campus Xochimilco. Mexico City. C.P. 04960 \\ ${ }^{6}$ Probiomed, SA de CV, Cruce de Carreteras Acatzingo-Zumpahuacan S/N, Tenancingo, Edo. de México \\ 52400, México \\ Received 17 January 2011; revised 7 June 2011; accepted 12 August 2011; available online 1 September 2011
}

\begin{abstract}
The heavy metals at high concentration are generally toxic to the plants for their metabolism and growth; therefore, interactions among metals, rhizosphere microbes and plants have attracted attention because of the biotechnological potential of microorganisms for metal removal directly from contaminated soils or the possible transference of them to the plants. The aim of this study was to compare the relationships between the physiological in vitro characteristics of rhizobacteria isolated from plant metal accumulators and their distribution relating with the heavy metals content in contaminated soils. The results of this study showed that the heavy metals present in the rhizosphere of the plant species analyzed, decrease the microbial biomass and content of heavy metals caused a different distribution of rhizobacteria found. Gram negative rhizobacteria (90\%) and gram positive rhizobacteria (10\%) were isolated; all of them are metal-resistant rhizobacteria and $50 \%$ of the isolated rhizobacteria possess both traits: higher indol acetic acid and siderophore producers. The inoculation with these rhizosphere microorganisms that possess metal-tolerating ability and plant growth promoting activities, can be recommended with a practical importance for both metal-contaminated environment and plant growth promotion.
\end{abstract}

Keywords: Phytohormones; Phytoremediation; Plant growth-promoting rhizobacteria; Siderophores

\section{INTRODUCTION}

The interactions between plants and beneficial rhizosphere microorganisms can enhance biomass production and tolerance of the plants to heavy metals, making the microorganisms an important component of phytoremediation technology (Wenzel et al.,1999; Glick, 2003; Nouri et al., 2011). The heavy metals are generally toxic to most of the plants for their metabolism and growth, if the heavy metals concentrations exceed the maximum permissible limit. Thus, the development of phytoremediation strategies like the interactions in the rhizosphere of plants growing in contaminated soils

*Corresponding Author Email: rodorantes@yahoo.com.mx

Tel./ Fax: 555557296300 are important because of the biotechnological potential of microorganisms for metal removal directly from soil or the possible transference of them to the plants (Guo et al., 1996). The rhizosphere provides a complex and dynamic microenvironment where microorganisms, in association with roots, form unique communities that have considerable potential for plant growth promotion (Belimov et al., 2005) and detoxification of hazardous compounds (Black et al., 1993; De Souza et al., 1999). The addition of certain metal resistant microorganisms like Psychrobacter sp. SRA1, Bacillus cereus SRA10, Bacillus weihenstephanensis SRP12, Sphingomonas macrogoltabidus and Microbacterium liquefaciens, 


\section{R. Melo et al.}

can affect the trace metal mobility and availability to the plants through release of chelating agents, acidification, phosphate solubilization and redox changes (Abou-Shanab et al., 2003; Idris et al., 2004; Ma et al., 2009).

In mining sites, toxic heavy metals are known to adversely affect the number, activity and diversity of soil organisms, as well as to restrict the growth of the most tolerant plants (Wong, 2003). The endemic biodiversity present in many metalliferous sites offers huge potential for the development of environmental technologies. Unfortunately, the management of metalliferous ecosystems lacks the ecological understanding of how contaminants interact with ecosystem functions and biological communities (Ramsey et al., 2005); because aboveground plant and belowground microbial communities of terrestrial ecosystems are are closely related (Epelde et al., 2010).

Although many soil bacteria are tolerant to heavy metals and play important roles in mobilization or immobilization of heavy metals (Gadd, 1990), there are few studies of the rhizospheric bacteria of metal accumulating and hyperaccumulating plants and their involvement in the tolerance to and uptake of heavy metals by the plants (Belimov et al., 2005).

Free-living as well as symbiotic Plant growth promoting rhizobacteria (PGPR) can improve plant nutrition and growth, plant competitiveness and responses to external stress factors like drought and osmotic stress (Burd et al., 2000; Egamberdiyeva and Hoflich, 2004; Mantelin and Touraine, 2004; Dell'Amico et al., 2008). The rhizobacteria enhance the plant biomass and nutrients either by the solubilization of phosphate and other mineral complexes or by nitrogen fixation, the production of siderophores for the acquisition of trace metals or by the release of phytohormones for better root growth and controlling the effects of deleterious organisms (Sharma et al., 2005; 2008; Zhuang et al., 2007; Rau et al., 2009). Many studies have been conducted to evaluate the role of PGPR in phytoremediation efficiency action on metal contaminated soils (Khan, 2005); these bacteria generate a stimulating effect on the growth of plants, giving to them a continuous nutrients and hormones supply through their metabolic activities (Glick et al., 1998; Wu et al., 2005). The soil bacteria have a broad kind of mechanisms for surviving in environments under elevated heavy metals concentrations (Bremer and Geasey, 1993); one mechanism involved the localization of metal ions bound to their outer cell surface (Churchill et al., 1995), through the interaction with sulfhydryl groups of cysteine residues (Erbe et al., 1995) or organic materials that cells synthesize and release (Clarke et al., 1987).

Wu et al. (2009) mentioned that PGPR might have a potential to protect host plants from acute biotoxicity and make the phytoextraction of them more effective. The improvement of the interactions between plants and beneficial rhizospheric microbes can enhance biomass production and tolerance of the plants to heavy metals; thereby, isolation of microorganisms from contaminated environments with heavy metals makes the possibility of the isolation of metal resistant strains of importance for a given phytoextraction strategy (Ma et al., 2009).

The aim of this study was to compare the relationships between the physiological in vitro characteristics of rhizobacteria isolated from different plant species and their distribution related with the heavy metals content in metal contaminated soils.

\section{MATERIALS AND METHODS}

Isolation of rhizobacteria from a heavy metals contaminated soils

Several rhizobacteria were isolated from roots of six plant species: Acacia farnesiana (L.) Willd., Amaranthus hybridus, Brickellia veronicifolia (Khunth) A., Sporobolus indicus, and Viguiera dentata (Cav.) Spreng grown in metal contaminated soils located in Villa de la Paz in the state of San Luis Potosí, México, with high concentration of As (548 to $4694 \mathrm{mg} / \mathrm{kg}$ of dry soil), $\mathrm{Cu}$ (505 to 1154 (mg/kg of dry soil), $\mathrm{Pb}$ (476 to $754 \mathrm{mg} / \mathrm{kg}$ of dry soil) and Zn (1386 to $1766 \mathrm{mg} / \mathrm{kg}$ of dry soil) (Vásquez-Murrieta et al., 2006; FrancoHernández et al., 2010). The soils were selected from three sites with a different heavy metals gradient (Table 1) and three representative specimen plants with their rhizospheric soils were collected in 1st of August 2009, from each site.

The rhizobacteria were isolated by placing $1 \mathrm{~g}$ of rhizospheric soil from each plant samples, in a $50 \mathrm{~mL}$ Erlenmeyer flasks containing five of $0.1 \mathrm{~cm}$ diameter glass beads and $10 \mathrm{~mL}$ of sterile phosphate saline buffer $\left(1.44 \mathrm{~g} \mathrm{Na}_{2} \mathrm{HPO}_{4}, 0.24 \mathrm{~g} \mathrm{KH}_{2} \mathrm{PO}_{4}, 0.20 \mathrm{~g} \mathrm{KCl}, 8 \mathrm{~g} / \mathrm{L} \mathrm{NaCl}\right.$, $\mathrm{pH}=7.4$ ) and agitating the flasks for $30 \mathrm{~m}$ at room temperature. After agitation, $0.1 \mathrm{~mL}$ of appropriate serial dilutions $\left(10^{-1}\right.$ to $\left.10^{-7}\right)$ of each flask contents was placed onto agar Luria-Bertani (LB). The plates were incubated 
at $28^{\circ} \mathrm{C}$ for $24 \mathrm{~h}$ and the bacterial number was expressed as Colony forming units (CFU)/g of soil. The isolated rhizobacteria strains were maintained and preserved on LB medium plates for the conventional bacterial analyses such as cell form and size, gram staining and colony pigmentation performed for the rhizobacteria strains isolated and identified by the determination of gene $16 \mathrm{~S}$ rRNA sequences. Colony Polymerase chain reaction (PCR) for the in vitro amplification of DNA was performed from live cell cultured on agar LB medium plates. Cells were harvested after $24 \mathrm{~h}$ and processed for DNA isolation using the Allers and Linchen (2000) procedure. Using the purified genomic DNA, the molecular target gene $16 \mathrm{~S}$ rRNA was amplified using universal primer set $\mathrm{fD} 1$ and $\mathrm{rD} 1$ designed by Weisburg et al. (1991). Aliquots of PCR reaction products were electrophoresed in $1 \%$ agarose gel and then stained with ethidium bromide. These PCR products of the DNA templates amplified were purified and sequenced by the Unidad de Biotecnología y Prototipos de la FES-Iztacala (UNAM). The sequences were then compared to similar sequences in the databases using BLAST analysis (Basic Logical Alignment Search Tool, BLAST at NCBI).

\section{Evaluation of the IAA production of the isolated rhizobacteria}

The rhizobacteria isolated, were analyzed by their Indole acetic acid (IAA) production (Sheng and Xia, 2006; Zaidi et al., 2006) using the Salkowski reagent according to the method of Bric et al. (1991). Microorganisms inhabiting rhizospheres of various plants are likely to synthesize and release auxins as secondary metabolites. Plant morphogenic effects may also be a result of different ratios of these plant hormones produced by roots as well as by rhizosphere bacteria, which may exert pronounced effects on plant growth and establishment (Ahmad et al., 2005). Auxin production by the rhizobacterial strains was analyzed in the presence and absence of L-tryptophan (IAA precursor) and determined by colorimetric analysis. The assays were done taking $4.9 \mathrm{~mL}$ of sterile LB liquid media, added to culture tubes $(10 \times 15 \mathrm{~cm})$ and supplemented with L-tryptophan at final concentrations of 1,2 and $5 \mathrm{mg} / \mathrm{L}$. The culture tubes were inoculated with $0.1 \mathrm{~mL}$ of each rhizobacteria inoculum $\left(5 \times 10^{7}\right.$ cells $/ \mathrm{mL}$ in sterile distilled water $)$ and incubated at $28^{\circ} \mathrm{C}$ for $120 \mathrm{~h}$. After the incubation, the cultures were centrifuged at $3,500 \mathrm{rpm}$, at $25^{\circ} \mathrm{C}$ for $45 \mathrm{~min}$ to discard the bacteria pellets and to recover the supernatant where the auxins were excreted; $2 \mathrm{~mL}$ of each supernatants were mixed with $2 \mathrm{~mL}$ of Salkowski's coloring reagent and the development of a pink color indicates IAA production and was quantified reading its absorbance at $535 \mathrm{~nm}$ and the concentration was estimated by a standard IAA curve. The assays with and without L-tryptophan were performed by triplicate.

\section{Evaluation of the siderophores production of the isolated rhizobacteria}

The production of siderophores of the rhizobacterial isolates were assayed by the universal method of Schwyn and Neilands (1987) with Chrome azurol S. The assays were done using blue agar plates with LB medium containing the dye Chrome azurol S (LB-CAS) (Sheng et al., 2008), divided equally into 24 sectors and spot inoculated with a sterile toothpick and each colony of the rhizobacteria isolated separately. The plates were incubated at $28^{\circ} \mathrm{C}$ for $24 \mathrm{~h}$ and the development of yellow halo around the growth was considered as positive for siderophore production. The siderophore levels produced by the strains were recorded as the diameter of the yellow halo produced around the colonies. The assays were performed by triplicate.

\section{Statistical analysis}

All the results were analysed by ANOVA test and Tukey-Kramer method using the statistics program

Table 1: Content of the most abundant heavy metals founded in the analyzed rhizospheric soil samples

\begin{tabular}{|c|c|c|c|c|c|c|c|}
\hline Sites & $\begin{array}{l}\text { Altitude } \\
(\text { masl) }\end{array}$ & Latitude & Longitude & As & $\mathrm{Cu}$ & $\mathrm{Pb}$ & $\mathrm{Zn}$ \\
\hline & & & & \multicolumn{4}{|c|}{ (mg/kg of dry soil ) } \\
\hline $\mathrm{S} 1$ & 1786 & $23^{\circ} 14^{\prime \prime}$ & $100^{\circ} 25^{\prime}$ & $548 \mathrm{bc}$ & $505 \mathrm{~b}$ & $476 \mathrm{ab}$ & $1691 \mathrm{a}$ \\
\hline $\mathrm{S} 2$ & 1770 & $23^{\circ} 25^{\prime \prime}$ & $100^{\circ} 12^{\prime}$ & $8420 \mathrm{a}$ & $1154 \mathrm{a}$ & $754 \mathrm{a}$ & $1386 \mathrm{a}$ \\
\hline $\mathrm{S} 3$ & 1638 & $23^{\circ} 26^{\prime \prime}$ & $100^{\circ} 54^{\prime}$ & $4694 \mathrm{ab}$ & $727 \mathrm{~b}$ & $409 \mathrm{~b}$ & $1766 \mathrm{a}$ \\
\hline
\end{tabular}

The different letters shows statistic difference $(\mathrm{P}<0.05)$. masl: meters above sea level 
Graph Pad Instat Ver. 2.03 (Aceves, 2003). A linear regression equation between the IAA and siderophores production (halo diameter measurement) was introduced to establish the relationship between those plant promoting traits of the isolated rhizobacteria.

A numerical comparative analysis of the physiological traits of the rhizobacteria was done; a distance matrix was built using the conventional standard distance coefficient, a phenogram was build using the Unweighted pair group method of arithmetic averages (UPGMA) method and correlation coefficient of Pearson was obtained (Sneath and Sokal, 1973), using the NTSyS-PC version 2.11T (Numerical Taxonomy and Multivariate Analysis System) software (Rohlf, 2004).

\section{RESULTS AND DISCUSSION}

Isolated rhizobacteria characteristics from the plant species analyzed

There were ten isolated rhizobacteria from the plant species listed in Table 2; these rhizobacteria showed prolific growth having different morphological appearance on LB medium (Table 3). Most of the bacilli are gram negative $(90 \%)$ with a predominance of beige color, colony diameter size between 0.1 to $0.5 \mathrm{~cm}$ and rounded. All the rhizobacteria isolated were identified based on their $16 \mathrm{~S}$ rDNA sequence homology analysis (Table 2).

Total rhizobacteria counts (culturable) were between $2.8 \times 10^{3}$ to $4.1 \times 10^{5} \mathrm{CFU} / \mathrm{g}$ of soil: Acacia farnesiana $(4.1$ x $10^{5} \mathrm{CFU} / \mathrm{g}$ of soil) and Amaranthus hybridus $\left(6.2 \times 10^{4}\right.$ $\mathrm{CFU} / \mathrm{g}$ of soil) from soil site 1 , followed by plant species from site 2: Acacia farnesiana (1.8 x $10^{4} \mathrm{CFU} / \mathrm{g}$ of soil), Viguiera dentata $\left(4.9 \times 10^{3} \mathrm{CFU} / \mathrm{g}\right.$ of soil) and Brickellia veronicifolia $2.7 \times 10^{3} \mathrm{CFU} / \mathrm{g}$ of soil), also affecting soil microbial communities (Epelde et al., 2010). The present study agrees with Epelde et al. (2010) analysis of the microbial communities founded in their mine soil analyzed with total metal concentration of 48, 26, 328 and 113, 620 $\mathrm{mg} / \mathrm{kg} \mathrm{DW}$ soil for $\mathrm{Cd}, \mathrm{Pb}$ and $\mathrm{Zn}$, respectively, with a low number of rhizobacteria present in the rhizosphere of the plant species analyzed; they found only 1 to 4 microbial species, even though positive effects of microbes on plant growth are common in nutrient poor ecosystems like mine soils, where they enhance the supply of growth limiting nutrients making microbial activity of vital importance for plant development.

\section{Characterization of the IAA producers}

The rhizosphere is defined as the zone of soil in which microbes are influenced by the root system and many microbes isolated from the rhizosphere have root growth-stimulating or growth inhibiting properties. The results of the physiological characteristics evaluated, like IAA and siderophores production, are present in Table 4; the ten isolated rhizobacteria were screened for their ability to produce plant growth regulator the IAA, recording with different concentrations of tryptophan $(0,1,2$ and $5 \mathrm{mg} / \mathrm{L})$ that influence the concentration of it. The IAA production of the isolates without tryptophan was 7.6 to $18.7 \mu \mathrm{g} / \mathrm{mL}$ and in all isolated rhizobacteria there was a little increase in the production of the auxin in the presence of tryptophan; for $1 \mathrm{mg} / \mathrm{L}: 9.5$ to $20.9 \mu \mathrm{g} / \mathrm{mL}$, for $2 \mathrm{mg} / \mathrm{L}: 10.6$ to $25 \mu \mathrm{g} /$ $\mathrm{mL}$ and for $5 \mathrm{mg} / \mathrm{L}: 10.5$ to $23 \mu \mathrm{g} / \mathrm{mL}$.

Ahmad et al. $(2005 ; 2008)$ mentioned that there are numerous soil microflora involved in the synthesis of auxins in pure culture and soil (Barazani et al., 1999) and some microorganisms produce auxins in the presence of a suitable precursor such as L-tryptophan; in general, the IAA produced by the rhizobacteria promotes root growth by directly stimulating plant cell elongation or cell division (Glick and Penrose, 1998). Ma et al. (2009) and Zaidi et al. (2006) mentioned that IAA production plays an important role in plantbacterial interactions and plant growth in metal contaminated soils. Khalid et al. (2004) categorized the in vitro production of IAA by rhizobacteria in three principal groups: lower producers (1 to $10 \mu \mathrm{g} / \mathrm{mL}$ ), medium producers (11 to $20 \mu \mathrm{g} / \mathrm{mL}$ ) and higher producers ( 21 to $30 \mu \mathrm{g} / \mathrm{mL}$ ). According to Khalid et al. (2004), the isolated rhizobacteria could be classified as follows: Pseudomonas sp. strain $\mathrm{C} 4$ and Enterobacter sp. strain $\mathrm{Sp} 4 \mathrm{C}$ as lower producers $(7.6$ and $9.9 \mu \mathrm{g} / \mathrm{mL}$, respectively) and the seven rhizobacteria: Bacillus $s p$. strain C3, Pseudomonas sp. strain C8, Pseudomonas sp. strain $\mathrm{Sp} 7 \mathrm{D}$, Serratia sp. strain $\mathrm{Sp} 3 \mathrm{~B}$, Achromobacter sp. strain C1, Pseudomonas sp. strain $\mathrm{Sp} 7 \mathrm{E}$ and Acinetobacter sp. strain $\mathrm{C} 7$ as medium producers (10 to $14.5 \mu \mathrm{g} / \mathrm{mL}$ ).

Case apart is the rhizobacteria Pseudomonas sp. strain $\mathrm{C} 2$ as the only higher producer with $25 \mu \mathrm{g} / \mathrm{mL}$ with $2 \mathrm{mg} / \mathrm{L}$ of Trp, instead of its production without $\operatorname{Trp}(18.7 \mu \mathrm{g} / \mathrm{mL})$. The results obtained from these rhizobacteria of present study were lower than the reported by Ma et al. (2009); their highest producer of IAA $(87.7 \mu \mathrm{g} / \mathrm{mL})$ isolated from the rhizosphere of Alyssum serpyllifolium and Phleum phleoides, and compared to the results obtained by Ahmad et al. (2005) 
Table 2: CFU/g of soils of the rhizobacteria isolated from the rhizospheric soil of each plant species from contaminated soils with heavy metals

\begin{tabular}{|c|c|c|c|c|}
\hline Soil site & Plant species & $\begin{array}{c}\mathrm{CFU} / \mathrm{g} \text { of } \\
\text { rhizospheric soil }\end{array}$ & Identified rhizobacteria & Identity $(\%)$ \\
\hline \multirow[t]{4}{*}{1} & Amaranthus hybridus & $6.2 \times 10^{4}$ & Serratia sp.strain $\mathrm{Sp} 3 \mathrm{~B}$ & 91 \\
\hline & Acacia farnesiana (L.) Willd. & $4.1 \times 10^{5}$ & Bacillus sp. strain $\mathrm{C} 3$ & 91 \\
\hline & Acacio farnesiang (I ) Willd & $1.8 \times 10^{4}$ & Enterobacter sp. strain $\mathrm{Sp} 4 \mathrm{C}$ & 92 \\
\hline & Acacta Jarnestana (L.) willa. & & Pseudomonas sp. strain C4 & 99 \\
\hline \multirow[t]{4}{*}{2} & \multirow{2}{*}{ Brickellia veronicifolia (Khunth) A. Gray } & $2.7 \times 10^{3}$ & Acinetobacter sp. strain $\mathrm{C} 7$ & 83 \\
\hline & & & Pseudomonas sp. strain C8 & 98 \\
\hline & \multirow[b]{2}{*}{ Viguiera dentata (Cav.) Spreng. } & $4.9 \times 10^{3}$ & Pseudomonas sp. strain Sp7D & 95 \\
\hline & & & Pseudomonas sp. strain $\mathrm{Sp} 7 \mathrm{E}$ & 94 \\
\hline \multirow[t]{2}{*}{3} & Sporobolus indicus & $2.8 \times 10^{3}$ & Achromobacter sp. strain $\mathrm{C} 1$ & 98 \\
\hline & & & Pseudomonas sp. strain $\mathrm{C} 2$ & 96 \\
\hline
\end{tabular}

Table 3: Colony and microscopy morphological characteristics of the ten isolated rhizobacteria from heavy metals contaminated soils

\begin{tabular}{|c|c|c|c|c|c|c|c|c|c|c|c|}
\hline Rhizobacteria & $\begin{array}{l}\text { Soil } \\
\text { Site }\end{array}$ & Form & Size & Color & Edge & Surface & Aspect & Consistence & Elevation & $\begin{array}{c}\text { Reflect } \\
\text { light }\end{array}$ & Gram behavior \\
\hline Sp3B & 1 & Round & $0.5 \mathrm{~cm}$ & Red & Complete & Smooth & Wet & Soft & Convex & Brilliant & Bacilli gram - \\
\hline $\mathrm{C} 3$ & 1 & Round & $0.4 \mathrm{~cm}$ & Beige & Complete & Smooth & Dry & Soft & Crater form & Mate & Bacilli gram + \\
\hline $\mathrm{C} 4$ & 2 & Round & $0.3 \mathrm{~cm}$ & Beige & Complete & Smooth & Wet & Soft & Pulvinate & Brilliant & Bacilli gram - \\
\hline $\mathrm{C} 7$ & 2 & Round & $0.2 \mathrm{~cm}$ & Beige & Complete & Smooth & Wet & Soft & Convex & Brilliant & Coc-Bac gram - \\
\hline $\mathrm{C} 8$ & 2 & Amoeboid & Irregular & Beige & Undulate & Smooth & Wet & Mucous & Elevate & Brilliant & Bacilli gram - \\
\hline $\mathrm{Sp} 4 \mathrm{C}$ & 2 & Round & $0.2 \mathrm{~cm}$ & Beige & Complete & Smooth & Wet & Soft & Convex & Brilliant & Bacilli gram - \\
\hline Sp7D & 2 & Round & $0.3 \mathrm{~cm}$ & Beige & Complete & Smooth & Wet & Soft & Convex & Brilliant & Bacilli gram - \\
\hline Sp7E & 2 & Round & $0.2 \mathrm{~cm}$ & Beige & Complete & Smooth & Wet & Soft & Convex & Brilliant & Bacilli gram - \\
\hline $\mathrm{C} 1$ & 3 & Amoeboid & Irregular & Beige & Undulate & Smooth & Wet & Mucous & Elevate & Brilliant & Bacilli gram - \\
\hline $\mathrm{C} 2$ & 3 & Round & $0.1 \mathrm{~cm}$ & Clear yellow & Complete & Smooth & Wet & Soft & Convex & Brilliant & Bacilli gram - \\
\hline
\end{tabular}

Table 4: Phytohormones and siderophores production by the ten isolated rhizobacteria from heavy metals contaminated soils

\begin{tabular}{|c|c|c|c|c|c|c|c|c|}
\hline \multirow[b]{2}{*}{ Rhizobacteria } & \multirow[b]{2}{*}{$\begin{array}{l}\text { Soil } \\
\text { site }\end{array}$} & \multirow[b]{2}{*}{ Basal } & \multicolumn{3}{|c|}{ Indol acetic acid produced $(\mu \mathrm{g} / \mathrm{mL})$} & \multicolumn{3}{|c|}{ Siderophores production } \\
\hline & & & $\begin{array}{l}1 \mathrm{mg} / \mathrm{L} \\
\operatorname{Trp}\end{array}$ & $\begin{array}{c}2 \mathrm{mg} / \mathrm{L} \\
\text { Trp }\end{array}$ & $\begin{array}{l}5 \mathrm{mg} / \mathrm{L} \\
\text { Trp }\end{array}$ & $\begin{array}{c}\text { Colony } \\
\text { diameter }(\mathrm{cm})\end{array}$ & $\begin{array}{c}\text { Yellow halo } \\
\text { diameter }(\mathrm{cm})\end{array}$ & $\begin{array}{c}\text { Siderophores } \\
\text { production } \\
\text { (Yellow halo \%) }\end{array}$ \\
\hline Serratia sp.strain Sp3B & 1 & $13.2 \pm 1.6$ & $10.2+4.7 b$ & $18.4 \pm 3.3$ & $12.7 \pm 4.5$ & $0.44+0.05 a b c$ & $0.14 \pm 0.05 \mathrm{c}$ & 14 \\
\hline Bacillus sp. strain C3 & 1 & $10.0 \pm 0.4 a$ & $9.5 \pm 0.5 b$ & $13.0 \pm 1.5 \mathrm{a}$ & $10.5 \pm 1.1 \mathrm{a}$ & $0.39 \pm 0.05 \mathrm{abc}$ & $0.29 \pm 0.06 \mathrm{c}$ & 29 \\
\hline Pseudomonas sp. strain $\mathrm{C} 4$ & 2 & $7.6 \pm 0.1 \mathrm{~b}$ & $10.7 \pm 0.1 \mathrm{a}$ & $10.6 \pm 0.0 \mathrm{~b}$ & $10.7 \pm 0.1 \mathrm{a}$ & $0.47 \pm 0.04 c$ & $0.15 \pm 0.05 \mathrm{c}$ & 15 \\
\hline Acinetobacter sp. strain $\mathrm{C} 7$ & 2 & $14.5 \pm 2.1$ & $11.5 \pm 1.6 \mathrm{a}$ & $14.6 \pm 1.9$ & $12.4 \pm 3.2$ & $0.44 \pm 0.05 \mathrm{abc}$ & $0.44 \pm 0.05 \mathrm{c}$ & 44 \\
\hline Pseudomonas sp. strain C8 & 2 & $10.2 \pm 0.6 \mathrm{a}$ & $12.6 \pm 2.9$ & $17.5 \pm 5.4$ & $15.4 \pm 1.4$ & $0.44 \pm 0.05 \mathrm{abc}$ & $0.51 \pm 0.07 \mathrm{ac}$ & 51 \\
\hline Enterobacter sp. strain $\mathrm{Sp} 4 \mathrm{C}$ & 2 & $9.9 \pm 1.9 \mathrm{a}$ & $16.2 \pm 4.5$ & $16.4 \pm 1.3$ & $15.3 \pm 3.3$ & $0.44 \pm 0.05 \mathrm{abc}$ & $0.17 \pm 0.06 \mathrm{bc}$ & 17 \\
\hline Pseudomonas sp. strain Sp7D & 2 & $11.7 \pm 0.9$ & $14.7 \pm 0.3$ & $12.5 \pm 1.7 \mathrm{a}$ & $13.2 \pm 2.8$ & $0.49 \pm 0.05 \mathrm{abc}$ & $0.27 \pm 0.06 \mathrm{bc}$ & 27 \\
\hline Pseudomonas sp. strain Sp7E & 2 & $14.5 \pm 1.5$ & $10.2 \pm 0.7 \mathrm{~b}$ & $14.2+6.2$ & $15.8 \pm 0.2$ & $0.42 \pm 0.04 c$ & $0.73 \pm 0.1 \mathrm{c}$ & 73 \\
\hline Achromobacter sp. strain $\mathrm{C} 1$ & 3 & $13.3 \pm 5.9$ & $20.9 \pm 4.9 \mathrm{ab}$ & $18.1 \pm 4.9$ & $16.6 \pm 9.8$ & $0.35 \pm 0.05 \mathrm{ac}$ & $0.42 \pm 0.05 \mathrm{ac}$ & 42 \\
\hline Pseudomonas sp. strain $\mathrm{C} 2$ & 3 & $18.7 \pm 4.1 \mathrm{ab}$ & $17.1 \pm 2.7$ & $25.0 \pm 6.2 \mathrm{al}$ & $23.0 \pm 4.2 \mathrm{a}$ & $0.40 \pm 0.02 \mathrm{ac}$ & $0.59 \pm 0.06 \mathrm{c}$ & 59 \\
\hline
\end{tabular}

Mean values \pm S.D. from three replicates for IAA production and seventy five replicates for siderophores production. The different lower-case letters show the significant differences between experiments $(\mathrm{p}<0.05)$. Trp: Tryptophan

for their 21 isolates of Azotobacter and Pseudomonas sp. with different tryptophan concentrations.

Fig. 1 shows the phenogram with the associated groups according with the IAA production; in this figure two groups forming at first: group I made only by Pseudomonas sp. strain C2 with the highest production of IAA and the rest of the rhizobacteria comprise the group II; in this group Achromobacter sp. strain $\mathrm{C} 1$ is separate of the rest (group IIa) and the other rhizobacteria forming the group $\mathrm{IIb}$ constitute the medium (group IV) and lower (group III) IAA producers.

\section{Characterization of the siderophores producers}

The siderophores are another important metabolites released by the plant growth promoting rhizobacteria 
that indirectly alleviate heavy metal toxicity by increasing the supply of iron to the plant (Burd et al., 1998, 2000; Ma et al., 2009). Heavy metals in soils could stimulate the production of bacterial siderophores (Whithing et al., 2001) that, in turn, alleviate metal toxicity to in plants (Burd et al., 2000; Dell' Amico et al., 2005). The isolated rhizobacteria from these plant species and soil samples with heavy metals contaminants, showed a direct relationship between the heavy metal content in soils and the higher production of siderophores. Based on the yellow diameter produced (lower siderophores producers $<$ $0.2 \mathrm{~cm}$, medium siderophores producers between 0.2 to $0.5 \mathrm{~cm}$ and higher siderophores producers $>0.5 \mathrm{~cm}$ ), the isolated siderophore producer rhizobacteria were classified (Fig. 2) and two groups were obtained from Fig. 2. It may be observed that group I associate the higher siderophores producers formed by group Ia: Pseudomonas sp. strain $\mathrm{Sp} 7 \mathrm{E}$ ( $0.73 \mathrm{~cm}$ of halo diameter), group Ib: Achromobacter sp. strain $\mathrm{C} 1$ and Acinetobacter sp. strain C7 ( 0.42 and $0.44 \mathrm{~cm}$ of halo diameter, respectively) and group Ic: Pseudomonas $s p$. strain $\mathrm{C} 2$ and Pseudomonas sp. strain C8 (0.59 and $0.51 \mathrm{~cm}$ of halo diameter, respectively); group II constitutes the rest of the rhizobacteria by group IIa (the medium siderophores producers): Bacillus $s p$. strain $\mathrm{C} 3$ and Pseudomonas sp. strain $\mathrm{Sp} 7 \mathrm{D}(0.29$ and $0.27 \mathrm{~cm}$ of halo diameter, respectively) and group IIb (the lower siderophores producers): Serratia sp. strain Sp3B, Pseudomonas sp. strain C4 and Enterobacter $s p$. strain $\mathrm{Sp} 4 \mathrm{C}(0.14,0.15$ and $0.17 \mathrm{~cm}$ of halo diameter, respectively). According to this study and its agreement with the results reported by Ma et al. (2009), siderophores produced by these rhizobacteria can help in plant root proliferation and enhancement of soil minerals uptake. Many of the rhizobacteria isolated (Serratia liquefaciens, Pseudomonas tolaasii, Pseudomonas fluorescens, Ralstonia taiwanenses) were capable of producing IAA and siderophores; significant differences between these rhizobacteria were also observed in the amount of IAA and siderophores produced: Variovorax paradoxus (AY196950) with $0.4 \mu \mathrm{g}$ of IAA/mg and $29 \mathrm{mM}$ of deferoxamine mesylate/mg, Variovorax paradoxus (AY196998) with $6 \mu \mathrm{g}$ of IAA/mg and $27 \mathrm{mM}$ of deferoxamine mesylate/mg, Pseudomonas sp. with $3 \mu \mathrm{g}$ of IAA $/ \mathrm{mg}$ and $90 \mathrm{mM}$ of deferoxamine mesylate/ mg (Belimov et al., 2005). Fig. 3 shows the correlation between the IAA production and the siderophores production (yellow halo diameter) of the isolated rhizobacteria: The rhizobacteria with higher IAA and siderophores production was Pseudomonas sp. strain $\mathrm{C} 2$, the rhizobacteria with higher siderophores production and medium IAA production was Pseudomonas sp. strain Sp7E, the rhizobacteria with higher siderophores production and lower IAA production was Pseudomonas $s p$. strain $\mathrm{C} 8$, the rhizobacteria with higher IAA production and medium siderophores production were Achromobacter $s p$. strain $\mathrm{C} 1$ and Acinetobacter sp. strain $\mathrm{C} 7$ and a big group of rhizobacteria with medium IAA production and lowest siderophores production were: Serratia $s p$. strain $\mathrm{Sp3B}>$ Pseudomonas sp. strain $\mathrm{Sp7D}>$ Enterobacter sp. strain $\mathrm{Sp} 4 \mathrm{C}>$ Bacillus sp. strain $\mathrm{C} 3$ $>$ Pseudomonas sp. strain C4. Finally, the results of this study showed that the heavy metals present as contaminants in the rhizosphere of the plant species analyzed, decrease the microbial biomass, in agreement with the report of Li et al. (2005) and Rau et al. (2009) on heavy metal contaminated soils. Nutrient acquisition has been considered as the primary factor to determine the ecological success of a species at the stressed sites and the cell shape has physiological significance in determining the ability of bacterial species to take up the nutrients (Young, 2006). Rau et al. (2009) mentioned that the dominance of bacilli cell shape provides ecological advantage to maximize the nutrient uptake and the dominance of both gramnegative and gram-positive rhizobacteria has been reported at metal contaminated sites by Frostegård et al. (1993) and Abaye et al. (2005). Even metals exert their toxic effects on microorganisms through various mechanisms; the metal-tolerant bacteria could survive in these habitats and could be isolated and selected for their potential application in the bioremediation of contaminated sites (Piotrowska-Seget et al., 2005; Ma et al., 2009).

\section{CONCLUSION}

This work analyzed the different associated rhizobacteria with plant species distributed in different soils with high heavy metals concentration. Gramnegative rhizobacteria $(90 \%)$ and gram-positive rhizobacteria $(10 \%)$ were islolated and characterized by their plant growth promoting traits like IAA and siderophores production that help plants and may protect them against the contaminant environment. Fifty percent of isolated rhizobacteria have both traits, 


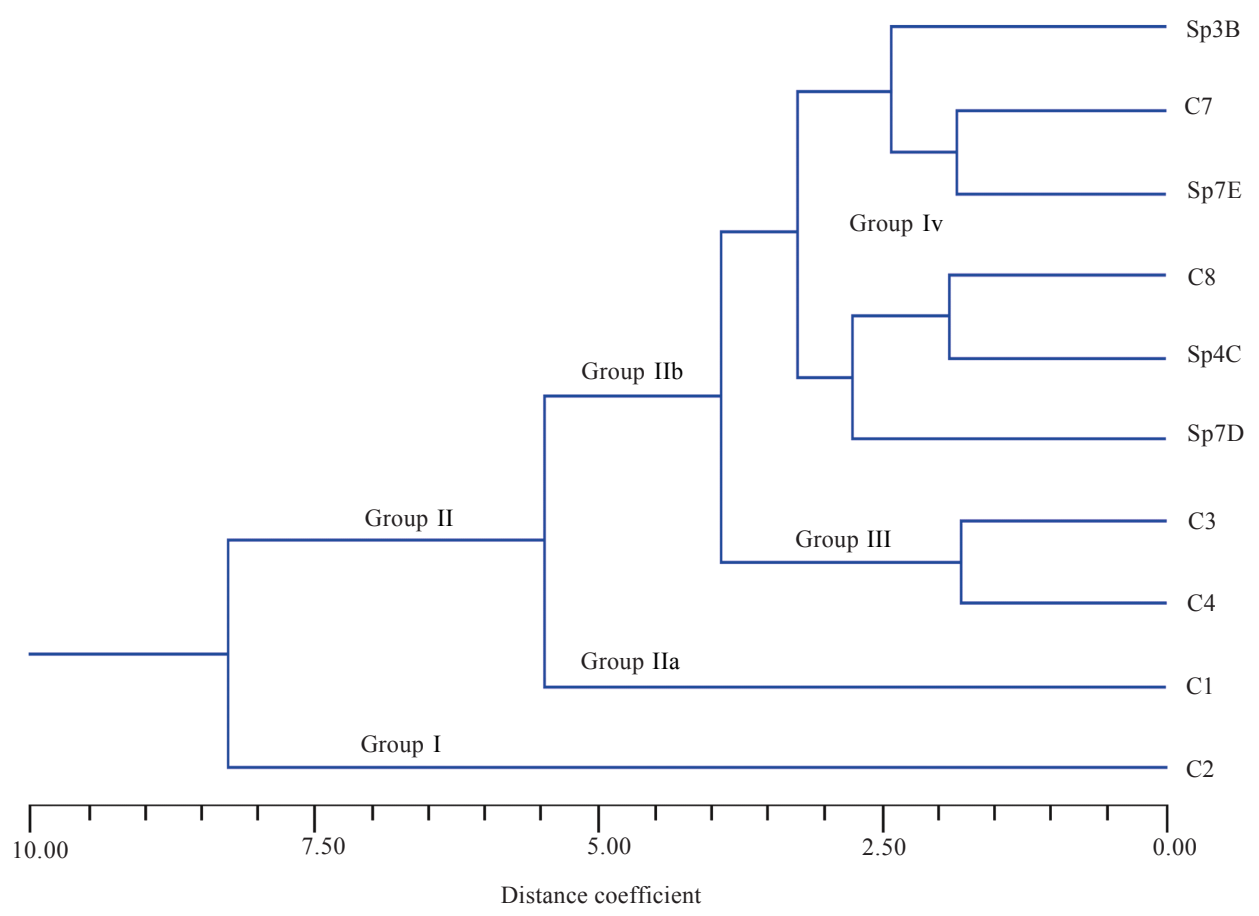

Fig. 1: Phenogram of the isolated rhizobacteria related with their IAA production trait $(\mathrm{r}=0.89)$

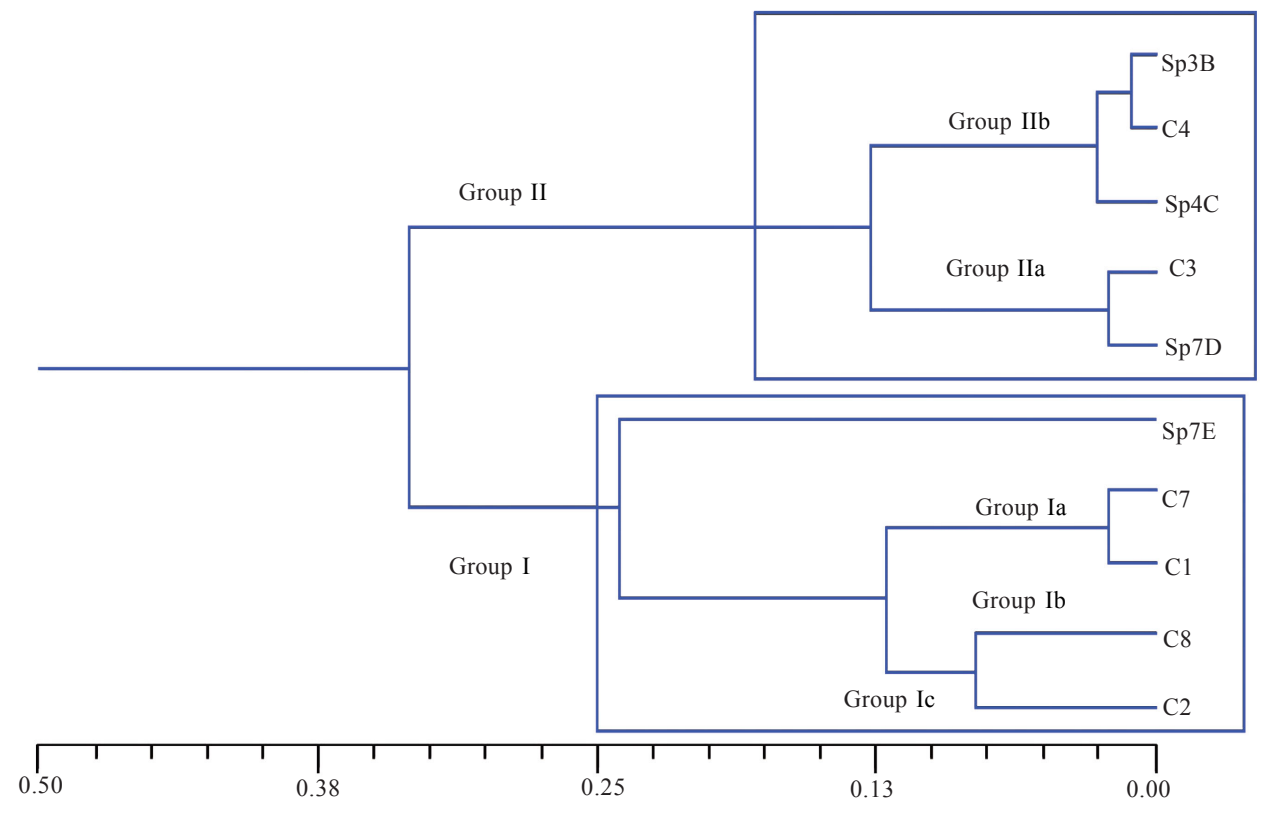

Distance coefficient

Fig. 2: Phenogram of the isolated rhizobacteria related with their siderophores production trait $(\mathrm{r}=0.76)$

are higher IAA and siderophore producers, and all of them are metal-resistant rhizobacteria related with the soil samples where they were isolated with high heavy metals concentration. There are further works with these isolated rhizobacteria that complete the effects of them as inoculants for the development of plant- 


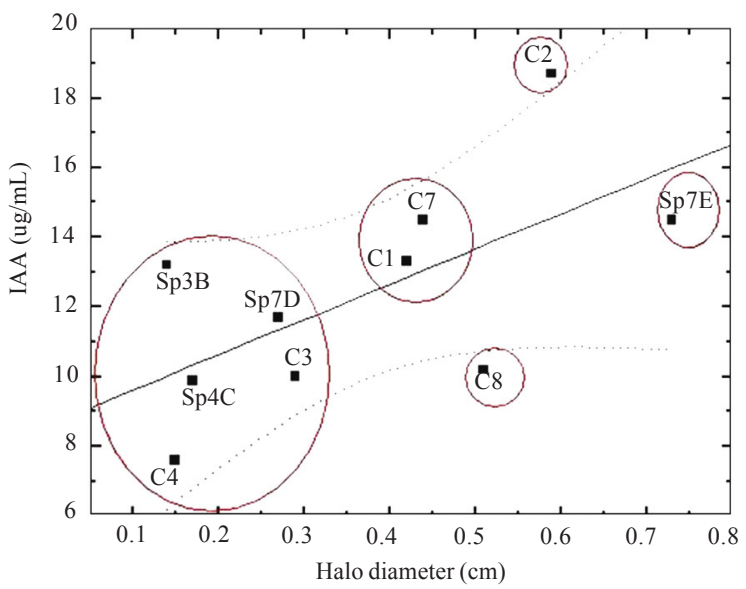

Fig. 3: Linear regression curve showing the relationship between IAA production $(\mu \mathrm{g} / \mathrm{mL})$ and sidrophores production (halo diameter $(\mathrm{cm})$ ), Strains are shown in the plot. Dotted lines show regression confidence area $(\mathrm{p}<0.05$, $\mathrm{r}=0.63$ )

microbe systems like experiments of seed inoculation. Therefore, inoculation with these rhizosphere microorganisms with metal-tolerating ability and plant growth promoting activities can be recommended with a practical importance for both metal contaminated environment and plant growth promotion.

\section{ACKNOWLEDGEMENTS}

Authors are grateful to the Research Project SIP: 20101639 of the Secretaría de Investigación y Posgrado del I.P.N., for providing the facilities to carry out this work and wish to thank the Comisión de Operación y Fomento de Actividades Académicas (COFAA) for its support throughout the development of this research work. Authors are also grateful for the SNI-CONACYT fellowship.

\section{REFERENCES}

Abaye, D. A.; Lawlor, K.; Hirsch, P. R.; Brookes, P. C., (2005). Changes in the microbial community of an arable soil caused by long-term metal contamination. Eur. J. Soil Sci., 56 (1), 93-102 (10 pages).

Abou-Shanab, R. A.; Angle, J. S.; Delorme, T. A.; Chaney, R. L.; van Berkum, P.; Moawad, H.; Ghanem, K.; Ghozlan, H. A., (2003). Rhizobacterial effects on nickel extraction from soil and uptake by Alyssum murale, New Phytol., 158 (1), 219-224 (6 pages).

Aceves, J., (2003). GraphPad Software. GraphPad InStat, V2.03

Ahmad, F.; Ahmad, I.; Khan, M. S., (2005). Indole acetic acid production by the indigenous isolates of Azotobacter and fluorescent Pseudomonas in the presence and absence of tryptophan. Turk. J. Biol., 29 (1), 29-34 (6 pages).

Ahmad, F.; Ahmad, I.; Khan, M. S., (2008). Screening of freeliving rhizospheric bacteria for their multiple plant growth promoting activities. Microbiol. Res., 163 (2), 173-181 (9 pages).

Allers, T.; Lichen, M., (2000). A method for preparing genomic DNA that restrains branch migration of Holiday junctions. Nucl. Aci. Res., 28 (2), 26-36 (11 pages).

Barazani, O. Z.; Friedman, J., (1999). Is IAA the major root growth factor secreted from plant-growth-mediating bacteria. J. Chem. Ecol., 25 (10), 2397-2406 (10 pages).

Belimov, A. A.; Hontzeas, N.; Safronova, V. I.; Demchinskaya, S. V.; Piluzza, G.; Bullitta, S.; Glick, B. R., (2005). Cadmiumtolerant plant growth-promoting bacteria associated with the roots of Indian mustard (Brassica juncea LCzern.). Soil Biol. Biochem., 37 (2), 241-250 (10 pages).

Black, R. C.; Choate, D. M.; Bardhan, S.; Revis, N.; Barton, L. L.; Zocco, T. G., (1993). Chemical transformation of toxic metals by a Pseudomonas strain from a toxic waste site. Environ. Toxicol. Chem., 12 (8),1365-1376 (12 pages).

Bric, J. M.; Bostock, R. M.; Silversone, S. E., (1991). Rapid in situ assay for indole acetic acid production by bacteria immobilization on a nitrocellulose membrane. Appl. Environ. Microbiol., 57 (2), 535-538 (4 pages).

Burd, G. I.; Dixon, D. G. ; Glick. B. R., (1998). A plant growthpromoting bacterium that decreases nickel toxicity in seedlings. Appl. Environ. Microbiol., 64 (10), 3663-3668 (6 pages).

Burd G. I.; Dixon, D. G.; Glick. B. R., (2000). Plant growthpromoting bacteria that decrease heavy metal toxicity in plants. Can. J. Microbiol., 46 (3), 237-245 (9 pages).

Churchill, S. A.; Walters, J. V.; Churchill, P. F., (1995). Sorption of heavy metals by prepared bacterial cell surfaces. J. Environ. Eng., 121 (10), 706-711 (6 pages).

Clarke, S. E.; Stuart, J.; Sandersloehr, J., (1987). Induction of siderophore activity in Anabaena species and its moderation of copper toxicity. Appl. Environ. Microbiol., 53 (5), $917-$ 922 (6 pages).

Dell' Amico, H.; Cavalca, L.; Andreoni, V., (2005). Analysis of rhizobacterial communities in perennial Graminaceae from polluted water meadow soil, and screening of metal-resistant, potentially plant growth-promoting bacteria. FEMS. Microbiol. Ecol., 52 (2), 153-162 (10 pages).

Dell'Amico, H.; Cavalca, L.; Andreoni, V., (2008). Improvement of Brassica napus growth under cadmium stress by cadmiumresistant rhizobacteria. Soil Biol. Biochem., 40 (1), 74-84 (11 pages).

De Souza, M. P.; Huang, C. P. A.; Chee, N.; Terry, N., (1999). Rhizosphere bacteria enhance that accumulation of selenium and mercury in wetland plants. Planta, 209 (2), 259-263 (5 pages).

Egamberdiyeva, D.; Hoflich, G., (2004). Effect of plant growthpromoting bacteria on growth and nutrient uptake of cotton and pea in a semi-arid region of Uzbekistan. J. Arid Environ., 56 (2), 293-301 (9 pages).

Epelde L.; Becerril, J. M.; Barrutia, O.; González-Oreja, J. A.; Garbisu, C., (2010). Interactions between plant and rhizosphere microbial communities in a metalliferous soil. Environ. Poll., 158 (5), 1576-1583 (8 pages).

Erbe, J. L.; Taylor, K. B.; Hall, L. M., (1995). Metalloregulation of the cyanobacterial smt locus: identification of the smtB binding sites and direct interaction with metals. Nucl. Acid 
Res., 23 (13), 2472-2478 (7 pages).

Franco-Hernández, M. O.; Vásquez-Murrieta, M. S.; PatiñoSiciliano, A.; Dendooven, L., (2010). Heavy metals concentration in plants growing on mine tailings in Central Mexico. Bioresour. Tech., 101 (11), 3864-3869 (6 pages).

Frostegård, A.; Tunlid, A.; Bååth, E., (1993). Phospholipid fatty acid composition, biomass and activity of microbial communities from two soil types experimentally exposed to different heavy metals. Appl. Environ. Microbiol., 59 (11), 3605-3617 (13 pages).

Gadd, G. M., (1990). Heavy metal accumulation by bacteria and other microorganisms. Experientia, 46 (8), 834-840 (7 pages).

Glick, B. R.; Penrose, D. M.; Li, J., (1998). A model for the lowering of plant ethylene concentrations by plant growth promoting bacteria. J. Theor. Biol., 190 (1), 63-68 (6 pages).

Glick, B. R., (2003). Phytoremediation: synergistic use of plants and bacteria to clean up the environment. Biotech. Adv., 21 (5), 383-393 (11 pages).

Guo, L.; Andrews, J.; Riding, R.; Dennis, P.; Dresser, Q., (1996). Possible microbial effects on stable carbon isotopes in hotspring travertines. J. Sediment. Res., 66 (3), 468-473 (6 pages).

Idris, R.; Trifonova, M.; Puschenreiter,W.; Wenzel, W.; Sessitsch, A., (2004). Bacterial communities associated with flowering plants of the Ni hyperaccumulator Thlaspi goesingense. Appl. Environ. Microbiol., 70 (5), 2667-2677 (11 pages).

Khalid, A.; Arshad, M.; Zahir, Z. A., (2004). Screening plant growth-promoting rhizobacteria for improving growth and yield of wheat. J. Appl. Microbiol., 96 (3), 473-480 (8 pages).

Khan, A. G., (2005). Role of soil microbes in the rhizosphere of plants growing on trace metal contaminated soils in phytoremediation. J. Trace Elem. Med. Biol., 18 (4), 355364 (10 pages).

Li, J.; Zu, J.; Tang, C.;Wu, J.; Muhammad, A.;Wang, H., (2005). Application of $16 \mathrm{~S}$ rDNA PCR amplification and DDGE fingerprinting for detection of shift in microbial community diversity in $\mathrm{Cu}, \mathrm{Zn}$ and $\mathrm{Cd}$ contaminated paddy soils. Chemosphere, 62 (8), 1375-1380 (6 pages).

Ma, Y.; Rajkumar, M.; Freitas, H., (2009). Improvement of plant growth and nickel uptake by nickel resistant-plantgrowth promoting bacteria. J. Hazard. Mater., 166 (2-3), 1154-1161 (8 pages).

Mantelin, S.; Touraine, B., (2004). Plant growth-promoting bacteria and nitrate availability: impacts on root development and nitrate uptake. J. Exp. Bot., 55 (394), 27-34 (8 pages).

Nouri, J.; Lorestani, B.; Yousefi, N.; Khorasani, N.; Hasani, A. H.; Seif, S.; Cheraghi, M., (2011). Phytoremediation potential of native plants grown in the vicinity of Ahangaran lead-zinc mine (Hamedan, Iran). Environ. Earth Sci., 62 (3), 639-644 (6 pages).

Piotrowska-Seget, Z.; Cycon, M.; Kozdroj, J., (2005). Metaltolerant bacteria occurring in heavily polluted soil and mine spoil. Appl. Soil Ecol., 28 (3), 237-246 (10 pages).

Ramsey, P. W.; Rillig, M. C.; Feris, K. P.; Gordon, N. S.; Moore, J. N.; Holben, W. E.; Gannon, J. E., (2005). Relationship between communities and processes; newinsights froma field study of a contaminated ecosystem.
Ecol. Lett., 8 (11), 1201-1210 (10 pages).

Rau, N.; Mishra, V.; Sharma, M.; Das, M.; Ahaluwalia, K.; Sharma, R. S., (2009). Evaluation of functional diversity in rhizobacterial taxa of a wild grass (Saccharum ravennae) colonizing abandoned fly ash dumps in Delhi urban ecosystem. Soil. Biol. Biochem., 41 (4), 813-821 (9 pages).

Rohlf, J., (2004). NTSYS-PC Version 2.11T. Numerical Taxonomy and Multivariate Analysis System. Applied Bioestastistics, Inc.

Schwyn, B.; Neilands, J. B., (1987). Universal chemical assay for the detection and determination of siderophores. Analys. Biochem., 160 (1), 47-56 (10 pages).

Sharma, M.; Rau, N.; Mishra, V.; Sharma, R. S., (2005). Unexplored ecological significance of Saccharum munja. Species, 43, 22 (1 pages).

Sharma, R. S.; Mishra, V.; Mohmmed, A.; Babu, C. R., (2008). Phage specificity and lipopolysaccharides of stem- and rootnodulating bacteria (Azorhizobium caulinodans, Sinorhizobium spp., and Rhizobium spp.) of Sesbania spp. Arch. Microbiol., 189 (4), 411-418 (8 pages).

Sheng, X. F.; Xia, J. J., (2006). Improvement of rape (Brassica napus) plant growth and cadmium uptake by cadmiumresistant bacteria. Chemosphere, 64 (6), 1036-1042 ( 7 pages).

Sheng, F. X.; Xia, J. J.; Jiang, Ch.Y.; He, L. Y.; Qian, M., (2008). Characterization of heavy metal-resistant endophytic bacteria from rape (Brassica napus) roots and their potential in promoting the growth and lead accumulation of rape. Environ. Poll., 156 (3), 1164-1170 (7 pages).

Sneath, P. H. A.; Sokal, R. R., (1973). Numerical Taxonomy: the principles and practice of numerical classification. Freeman, San Francisco.

Vásquez-Murrieta, M. S.; Migueles-Garduño, I.; FrancoHernández, O.; Govaerts, B.; Dendooven, L., (2006). C and $\mathrm{N}$ mineralization and microbial biomass in heavy metalcontaminated soil. Eur. J. Soil, Biol., 42 (2), 89-98 (10 pages).

Wardle, D. A.; Bonner, K. I.; Barker, G. M.; Yeates, G. W.; Nicholson, K. S.; Bardgett, R. D.; Watson, R. N.; Ghani, A., (1999). Plant removals in perennial grassland: vegetation dynamics, decomposers, soil biodiversity, and ecosystem properties. Ecol. Monogr., 69 (4), 535-568 (33 pages).

Weisburg, W. G.; Barns, S. M.; Pelletier, D. A.; Lane, D. J., (1991). 16Ribosomal DNA amplification for phylogenetic study. J. Bacteriol., 173 (2), 697-703 (7 pages).

Wenzel, W. W.; Lombi, E.; Adriano, D. C., (1999). Biogeochemical processes in the rhizosphere: role in phytoremediation of metal-polluted sites. in: Prasad, M.N.V., Hagemeyer, J. (Eds.), Heavy Metal Stress in Plants: from Molecules to Ecosystems. Springer, Heidelberg, Berlin, New York.

Whiting, S. N.; De Souza, M. P.; Terry, N., (2001). Rhizosphere bacteria mobilize $\mathrm{Zn}$ for hyperaccumulation by Thlaspi caerulescens. Environ. Sci. Tech., 35 (15), 31443150 (7 pages).

Wong, M. H., (2003). Ecological restoration of mine degraded soils, with emphasis on metal contaminated soils. Chemosphere, 50 (6), 775-780 (6 pages).

Wu, S. C.; Cao, Z. H.; Li, Z. G.; Cheung, K. C.; Wong, M. H., (2005). Effects of biofertilizer containing N-fixer, P and K 


\section{R. Melo et al.}

solubilizers and AM fungi on maize growth: a greenhouse trial. Geoderma, 125 (1-2), 155-166 (12 pages).

Wu S.C.; Peng, X. L.; Cheung, K. C.; Liu, S. L.; Wong, M. H., (2009). Adsorption kinetics of $\mathrm{Pb}$ and $\mathrm{Cd}$ by two plant growth promoting rhizobacteria. Bioresour. Tech., 100 (20), 4559-4563 (5 pages).

Young, K. D., (2006). The selective value of bacterial shape. Microbiol. Mol. Biol. R., 70 (3), 660-703 (44 pages).
Zaidi, S.; Usmami, S.; Singh, B. R.; Musarrat, J., (2006) Significancce of Bacillus subtilis strain SJ-101 as a bioinoculant for concurrent plant grown promotion and nickel accumulation in Brassica juncea. Chemosphere, 64 (6), 991-997 (7 pages).

Zhuang, X.; Chen, J.; Shim, H.; Bai, Z., (2007). New advances in plant growth promoting rhizobacteria for bioremediation. Environ. Int., 33 (3), 406-413 (8 pages).

\section{AUTHOR (S) BIOSKETCHES}

Melo, M. R., Botany Department, National Biological Sciences School, National Polytechnic Institute, 11340, D.F., México.

Email: honikza@hotmail.com

Flores, N. R., Botany Department, National Biological Sciences School, National Polytechnic Institute, 11340, D.F., México.

Email: wanda_nelly@hotmail.com

Murrieta, S. V., Microbiology Department, National Biological Sciences School, National Polytechnic Institute, 11340, D.F., México. Email:murrieta@hotmail.com

Tovar, A. R., Microbiology Department, National Biological Sciences School, National Polytechnic Institute, 11340, D.F., México, Email: avrodriguez1@yahoo.com.mx

Zúñiga, A. G., Petroleum Mexican Institute, 07730, D.F., México. Email: aguerrer@imp.mx

Hernández, O. F., Basic Sciences Department, Interdisciplinary Professional Unit of Biotechnology, National Polytechnic Institute, 11340, D.F., México. Email: mofrancoh@hotmail.com

Mendoza, A. P., Environmental Studies Institute, 68725, Ixtlán de Juárez, Oaxaca, México. Email: jano_ponce@hotmail.com

Pérez, N. O., Present address: Probiomed, SA de CV, Cruce de Carreteras Acatzingo-Zumpahuacan S/N, Tenancingo, Edo. de México, 52400, México. Email: nestor.perez@probiomed.com.mx

Dorantes, A. R., Botany Department, National Biological Sciences School, National Polytechnic Institute, 11340, D.F., México. Email: rodorantes@yahoo.com.mx

How to cite this article: (Harvard style)

Melo, M. R.; Flores, N. R.; Murrieta, S. V.; Tovar, A. R.; Zúñiga, A. G.; Hernández, O. F.; Mendoza, A. P.; Pérez, N. O.; Dorantes, A. R., (2011). Comparative plant growth promoting traits and distribution of rhizobacteria associated with heavy metals in contaminated soils. Int. J. Environ. Sci. Tech., 8 (4), 807-816. 